\title{
Food pattern and nutritional status of children with cerebral palsy
}

\author{
Padrão alimentar e estado nutricional de crianças com paralisia cerebral
}

Estándar alimentar y estado nutricional de niños con parálisis cerebral

Patrícia Ayrosa C. Lopes ${ }^{1}$ Olga Maria S. Amancio ${ }^{2}$, Roberta Faria C. Araújo', Maria Sylvia de S. Vitalle ${ }^{3}$, Josefina Aparecida P. Braga ${ }^{4}$

\section{ABSTRACT}

Objectives: To assess the food intake pattern and the nutritional status of children with cerebral palsy.

Methods: Cross-sectional study with 90 children from two to 12.8 years with cerebral palsy in the following forms: hemiplegia, diplegia, and tetraplegia. Nutritional status was assessed by weight, height, and age data. Food intake was verified by the 24 -hour recall and food frequency questionnaire. The ability to chew and/or swallowing, intestinal habits, and physical activity were also evaluated.

Results: For 2-3 year-old age group, the mean energy intake followed the recommended range; in 4-6 year-old age group with hemiplegia and tetraplegia, energy intake was below the recommended limits. All children presented low intake of carbohydrates, adequate intake of proteins and high intake of lipids. The tetraplegia group had a higher prevalence of chewing (41\%) and swallowing (12.8\%) difficulties compared to 14.5 and $6.6 \%$ of children with hemiplegia, respectively. Most children of all groups had a daily intestinal habit. All children presented mild physical activity, while moderate activity was not practiced by any child of the tetraplegia group, which had a significantly lower height/age $Z$ score than those with hemiplegia (-2.14 versus -1.05 ; $p=0.003)$.

Conclusions: The children with cerebral palsy presented inadequate dietary pattern and impaired nutritional status, with special compromise of height. Tetraplegia imposes

Instituição: Centro de Reabilitação de Deficientes Físicos e Mentais do Município de Santos, Santos, SP, Brasil

${ }^{1}$ Mestre em Ciências pelo Departamento de Pediatria da Escola Paulista de Medicina da Universidade Federal de São Paulo (Unifesp), São Paulo, $\mathrm{SP}$, Brasil

${ }^{2}$ Professora-Associada livre-docente do Departamento de Pediatria da Escola Paulista de Medicina da Unifesp, São Paulo, SP, Brasil

${ }^{3}$ Doutora em Medicina pela Escola Paulista de Medicina da Unifesp; Médica do Departamento de Pediatria da Escola Paulista de Medicina da Unifesp, São Paulo, SP, Brasil

${ }^{4}$ Doutora em Medicina pela Escola Paulista de Medicina da Unifesp; Professora-Adjunta do Departamento de Pediatria da Escola Paulista de Medicina da Unifesp. São Paulo, SP, Brasil difficulties regarding chewing/swallowing and moderate physical activity practice.

Key-words: brain damage, chronic; cerebral palsy; nutritional status; child.

\section{RESUMO}

Objetivo: Avaliar o padrão alimentar e o estado nutricional de crianças com paralisia cerebral.

Métodos: Estudo transversal com 90 crianças de dois a 12,8 anos de idade, com paralisia cerebral do tipo hemiplegia, diplegia e tetraplegia. Avaliaram-se o estado nutricional por meio dos dados de peso, altura e idade, o consumo alimentar pelo Recordatório de 24 horas e pelo Questionário de Frequência Alimentar, a capacidade de mastigar e/ou deglutir, o hábito intestinal e a prática de atividade física.

Resultados: No grupo de dois a três anos, a média de ingestão energética estava de acordo com a recomendação; na faixa de quatro a seis anos, os grupos com hemiplegia e com tetraplegia apresentaram médias abaixo do limite inferior da recomendação. O grupo como um todo apresentou padrão dietético baixo em carboidratos, adequado em proteína e alto em lipídios. O grupo com tetraplegia apresentou maior prevalência de dificuldade para mastigação (41\%) e para deglutição $(12,8 \%)$ versus, respectivamente, 14,5 e 6,6\% das crianças com hemiplegia. Observou-se que a maioria das crianças com cada tipo de paralisia cerebral apresentava hábito intestinal diário. Todas as crianças estudadas tinham
Endereço para correspondência:

Olga Maria S. Amancio

Rua Botucatu, 703

CEP 04023-062 - São Paulo/SP

E-mail: omsamancio.dped@epm.br

Conflito de interesse: nada a declarar

Recebido em: 31/7/2012

Aprovado em: 14/2/2013 
atividade física leve, enquanto a atividade moderada não era praticada por nenhuma criança do grupo com tetraplegia, que também apresentou escore $Z$ de -2,14 da relação estatura/ idade, significantemente menor em relação ao grupo com hemiplegia (escore $\mathbf{Z}$ de $-1,05$; $p=0,003$ ).

Conclusões: As crianças apresentaram padrão alimentar inadequado, estado nutricional comprometido, o que afetou principalmente a estatura. A tetraplegia impõe dificuldade de mastigação/deglutição e da prática de atividade física moderada.

Palavras-chave: dano encefálico crônico; paralisia cerebral; estado nutricional; criança.

\section{RESUMEN}

Objetivo: Evaluar el estándar alimentar y estado nutricional de niños con parálisis cerebral.

Métodos: Estudio transversal con 90 niños de 2 a 12,8 años de edad, con parálisis cerebral de tipo hemiplejía, diplejía y tetraplejía. Se evaluaron el estado nutricional por medio de los datos de peso, altura y edad, el consumo alimentar por el Recordatorio de 24 horas y por el Cuestionario de Frecuencia Alimentar, la capacidad de masticar y/o deglutir, el hábito intestinal y la práctica de actividad física.

Resultados: En el grupo de 2 a 3 años, el promedio de ingestión energética estaba conforme a la recomendación; en la franja de 4 a 6 años, los grupos con hemiplejía y con tetraplejía presentaban promedios inferiores al límite inferior de recomendación. El grupo como un todo presentó estándar dietético bajo en carbohidratos, adecuado en proteínas y alto en lípidos. El grupo con tetraplejía presentó mayor prevalencia de dificultad para masticación (41\%) y deglución $(12,8 \%)$, versus, respectivamente, 14,5 y $6,6 \%$ de los niños con hemiplejía. Se observó que la mayoría de los niños con cada tipo de parálisis cerebral presentaba hábito intestinal diario. Todos los niños estudiados tenían actividad física liviana, mientras que la actividad moderada no era practicada por ningún niño del grupo tetraplejía, que también presentó escore $Z$ de -2,14 de la relación estatura/edad, significantemente menor respecto al grupo con hemiplejía (escore $Z$ de $-1,05 ; p=0,003)$.

Conclusiones: Los niños presentaron estándar alimentar inadecuado, estado nutricional comprometido, principalmente la estatura. La tetraplejía impone dificultades de masticación/deglución y práctica de actividad física moderada.
Palabras clave: daño encefálico crónico; parálisis cerebral; estado nutricional; niño.

\section{Introduction}

Cerebral palsy (CP), also called non-progressive static encephalopathy, is the set of non-progressive brain disorders caused by brain injury that occurred during fetal life or in the first years of life ${ }^{(1)}$. The diagnosis is wideranging and depends on the severity of the topographic distribution (affected members), clinical history, and motor dysfunction ${ }^{(2)}$.

A number of other symptoms may be associated to motor disorders: mental retardation, epilepsy, hearing, language, ocular/visual, and behavior disorders ${ }^{(3)}$. According to Rotta ${ }^{(4)}$, the child with CP presents lower weight, and lower resistance to infections. Studies documented association between chewing and swallowing problems and nutritional impairment ${ }^{(5-7)}$. The chronic changes in swallowing can lead to malnutrition, dehydration, aspiration, and pneumonia ${ }^{(8)}$.

Studies have shown an association between chewing and swallowing difficulties and nutritional impairment $t^{(7,9)}$. In Brazil, Pires et $a l^{(10)}$, in a research involving children and adolescents with CP in São Paulo, found $63 \%$ prevalence of low birth weight in patients with tetraplegia. According to Santos and Serrano ${ }^{(11)}, 20 \%$ of children treated at the Association of Parents and Friends of Exceptional Children (Associação de Pais e Amigos dos Excepcionais - Apae) from Vale do Aço, (metropolitan area in the state of Minas Gerais) were malnourished, 65\% were at risk of malnutrition, and $50 \%$ presented iron deficiency anemia.

Given the importance of nutritional assessment, which can provide support to the most suitable individual treatment as well as to the planning of public health interventions, the present study aimed to assess the nutritional status, by anthropometry, and the dietary patterns of children with non-progressive chronic encephalopathy.

\section{Method}

This was an observational descriptive cross-sectional study, conducted by convenience sampling, involving 90 children of both genders, aged between two and 12.8 years, 
with CP followed at the Rehabilitation Center for Physical and Mental Disabilities (Centro de Reabilitação de Deficientes Físicos e Mentais) in the municipality of Santos, state of São Paulo. Data from January to May 2011 were collected. This study was approved by the Research Ethics Committee of Universidade Federal de São Paulo, and a previous written consent by parents or guardians was required.

The sample selection was conducted from the research in the medical records of all children and adolescents treated in that institution, which were signed by the neurologist on charge. Among the total of 232 records, there were 116 cases of CP. Children using nasogastric or gastrostomy feeding tube were excluded as were two others for frequent absences.

The classification by Rotta et $a l^{(12)}$ was used to classify the type of $\mathrm{CP}$, with the use of topographic distribution and the extent of impairment. We classified the studied group in cases of hemiplegia, diplegia, and tetraplegia.

The dietary assessment with the parents was performed using the 24-hour recall method ${ }^{(13)}$ and the Food Frequency Questionnaire $(\mathrm{FFQ})^{(14)}$. The intake of energy and macronutrients was calculated with the DietPro software, version 5.5i (Universidade Federal de Viçosa) ${ }^{(15)}$, with data from the 24-hour recall. The following percentages of total energy from macronutrients were considered adequate: 55-60\% carbohydrates, $10-15 \%$ protein, and $25-30 \%$ lipids $^{(16)}$. Values of energy and activity level were analyzed according to the American food guide ${ }^{(17)}$. It was necessary to stratify age for the analysis.
In the interview with parents, they were asked about the difficulty in chewing and/or swallowing solid foods; the number of meals/day (considering that four to five meals were appropriate); the practice of mild physical activity (only physiotherapy in the institution, once a week) and moderate physical activity (besides physiotherapy in the institution, 30 to 50 minutes of swimming, physical education or equine therapy); and bowel habit (daily, every other day, less than three times/week).

For height and weight measurements, the recommended techniques were employed. Estimates were used when the physical condition of the child did not allow the measurements. For estimated weight: the parents were weighed using only light clothing, without shoes; then they were weighed again with the child on their lap. The child's weight was obtained subtracting the values found. For estimated height, in centimeters, a bone caliper was used in order to measure knee length, to the calcaneus, with a $90^{\circ}$ angle between the leg and the tight of the patient, and height was calculated according to the formula proposed by Stevenson ${ }^{(18)}$ : $[\mathrm{E}(\mathrm{cm})=(2.69 \mathrm{xCJ})+24.2$, with a standard deviation of \pm 1.1$]$.

The Z score of body mass index-for-age (BMI/A) and heightfor-age $(H / A)$ of all participants was calculated. Specifically for children from 2 to 5 years, the $\mathrm{Z}$ score of weight-for-age (W/A) was calculated. Nutritional status was calculated according to recommendations of the World Health Organization $(\mathrm{WHO})^{(19)}$. Patients were classified as malnourished when $\mathrm{Z}$ score values were $\leq-2$.

Table 1 - Total energy consumption by children according to the type of cerebral palsy

\begin{tabular}{|c|c|c|c|c|}
\hline \multirow{2}{*}{ Age (years) } & \multicolumn{3}{|c|}{ Total energy intake (kcal/day) } & \multirow{2}{*}{$p$-value } \\
\hline & Hemiplegia & Diplegia & Tetraplegia & \\
\hline \multirow{2}{*}{$2-3$} & $\mathrm{n}=17$ & $n=2$ & $\mathrm{n}=12$ & \multirow{3}{*}{0.879} \\
\hline & $1135.9 \pm 579.1$ & $1351.5 \pm 686.6$ & $1179.5 \pm 564.7$ & \\
\hline $\operatorname{RV}[1,000-1,400 \mathrm{kcal}]$ & $(288-2433)$ & $(866-1837)$ & $(511-2128)$ & \\
\hline \multirow{2}{*}{$4-8$} & $\mathrm{n}=18$ & $n=1$ & $\mathrm{n}=18$ & \multirow{3}{*}{0.398} \\
\hline & $1383.2 \pm 530.7$ & $1801.0 \pm 0.0$ & $1302.9 \pm 544.8$ & \\
\hline $\operatorname{RV}[1,400-1,600 \mathrm{kcal}]$ & $(691.9-3071)$ & $(1801)$ & $(665-2509)$ & \\
\hline \multirow{3}{*}{$\begin{array}{l}9-13 \text { - boys } \\
\operatorname{RV}[1,800-200 \mathrm{kcal}]\end{array}$} & $n=5$ & & $n=4$ & \multirow{3}{*}{0.669} \\
\hline & $1816.2 \pm 1028.9$ & & $1575.7 \pm 306.6$ & \\
\hline & $(1028-3577)$ & & $(1317-2020)$ & \\
\hline \multirow{3}{*}{$\begin{array}{l}\text { 9-13 - girls } \\
\operatorname{RV}[1,600-2,000 \mathrm{kcal}]\end{array}$} & $n=8$ & & $n=5$ & \multirow{3}{*}{0.151} \\
\hline & $1756.5 \pm 348.5$ & & $1329.6 \pm 660.6$ & \\
\hline & $(1306-2360)$ & & $(732-2455)$ & \\
\hline
\end{tabular}

RV: reference values from the U.S. Department of Health and Human Services ${ }^{(17)}$; Numbers in brackets indicate the range of values found 
In statistical analysis, Student $t$ test, analysis of variance with one criterion, and Kruskal-Wallis test were used, according to the nature of the variables. Significance was established at $p<0.05$.

\section{Results}

The study sample consisted of 90 patients with chronic encephalopathy, from 2 to 12.8 years, of whom 52 were male and 38 , female. The mean age was $6.2 \pm 3.3$ years. Among the 90 children, $54 \%$ were classified with hemiplegia, $43 \%$ with tetraplegia, and $3 \%$ with diplegia.

Difficulty in chewing solid food was observed in 23 (26\%) cases and, for swallowing, in eight (9\%) cases. Children with diplegia had no difficulty in chewing and swallowing, while the quadriplegic children had a higher prevalence of chewing (41\%) and swallowing (12.8\%) problems, versus 14.5 and $6.6 \%$ of children with hemiplegia, respectively.

The percentage of total energy coming from macronutrients showed that for the group as a whole, there was a dietary pattern low in carbohydrates $(52 \%)$, adequate in protein (53\%), and high in lipids (43\%). The analysis according to the type of CP showed, in the group with hemiplegia, high intake of fat $(58 \%)$ and inadequate intake of carbohydrate and protein $(50 \%)$. In the group with tetraplegia, 64\% showed high fat intake, $62 \%$, low carbohydrate intake and $46 \%$, low protein intake.

The average energy consumption showed no significant difference in children with the various types of $\mathrm{CP}$, according to the age ranges. In the group of children from 2-3 years, the means were in agreement with the recommendation. In the age range of 4-6 years, the groups with hemiplegia and tetraplegia presented means below the lower limits of

Table 2 - Distribution of the population according to the type of cerebral palsy and second bowel habits and level of physical activity

\begin{tabular}{lccc}
\hline & \multicolumn{3}{c}{ Types of cerebral palsy } \\
\cline { 2 - 4 } & $\begin{array}{c}\text { Hemiplegia } \\
\mathbf{n}=\mathbf{4 8}\end{array}$ & $\begin{array}{c}\text { Diplegia } \\
\mathbf{n}=\mathbf{3}\end{array}$ & $\begin{array}{c}\text { Tetraplegia } \\
\mathbf{n}=\mathbf{3 9}\end{array}$ \\
\hline Bowel Habit & & & \\
$\quad$ Daily & 28 & 02 & 17 \\
$\quad \begin{array}{l}\text { Alternate days } \\
<3 \text { times/week }\end{array}$ & 06 & - & 08 \\
Physical Activity & 14 & 01 & 14 \\
$\quad$ Mild & 43 & 02 & 39 \\
$\quad$ Moderate & 05 & 01 & - \\
\hline
\end{tabular}

recommendation. In the age range from 9-13 years, both for boys and girls, the group with tetraplegia showed means of energy intake below the recommended (Table 1).

It was observed that most children with $\mathrm{CP}$ had daily bowel movements. The rest of each group showed predominantly less than three bowel movements a week, on alternate days. All children studied had mild physical activity. No children in the group with tetraplegia, five children in the group with hemiplegia, and one child in the group with diplegia reported moderate activity (Table 2).

In the group with diplegia (not considered in the statistical analyses of anthropometric data), only one in three children showed a $\mathrm{Z}$ score $=-2.40$ for $\mathrm{H} / \mathrm{A}$. On average, only the group with tetraplegia showed a $Z$ score for W/A near $-2(-1.88)$ and, as for the H/A Z score, a value of -2.14 , significantly lower than the group with hemiplegia $(p=0.019$ and $p=0.003$ ) was found. However, considering these two groups, $18 / 45$ children, it was observed that they showed a $\mathrm{Z}$ score $<-2$ for W/A; 20/87 for BMI/A, and 29/87 children for $\mathrm{H} / \mathrm{A} \mathrm{Z}$ score (Table 3).

\section{Discussion}

In the review of food consumption and anthropometric measures, the group with diplegia showed results that were not considered for statistical analysis, since their sample size (3) was not representative. In groups with hemiplegia and tetraplegia, it was observed that, until 3 years of age, energy intake remained adequate. From 3 to 12.8 years, this consumption was below the recommended, with values, on average, lower in the group with tetraplegia. This fact can be explained by the difficulty in chewing and swallowing that these individuals might have, which is more significant in

Table 3 - Nutritional status by anthropometry of children according to the types of hemiplegia and tetraplegia in cerebral palsy

\begin{tabular}{lccc}
\hline \multirow{2}{*}{$\begin{array}{l}\text { Type of } \\
\text { cerebral palsy }\end{array}$} & \multicolumn{3}{c}{ Z score } \\
\cline { 2 - 4 } & W/A & BMI/A & H/A \\
\hline Hemiplegia & $-1.02 \pm 1.89$ & $-0.16 \pm 1.92$ & $-1.05 \pm 1.60$ \\
[n=48] & $(-5.16 / 2.51)$ & $(-6.31 / 3.93)$ & $(-5.59 / 2.64)$ \\
Tetraplegia & $-1.88 \pm 1.98$ & $-1.23 \pm 2.25$ & $-2.14 \pm 2.38$ \\
[n=39] & $(-3.76 / 3.32)$ & $(-6.56 / 3.87)$ & $(-7.4 / 7.43)$ \\
$p$-value & 0.165 & 0.019 & 0.003 \\
\hline
\end{tabular}

BMI: body mass index; $\mathrm{H}$ : height; $\mathrm{A}$ : age; $\mathrm{W}$ : weight. W/A: children from 2-5 years old; BMI/A and H/A: children from 2 to 12.8 years; The numbers in brackets indicate the range of values found; $p$ descriptive level of Student $t$ test 
the group with tetraplegia, which may, perhaps, have been attenuated in the younger age groups due to food consistency of porridge and soups, more appropriate for this age group. The low energy intake is also reported by Sullivan et $\mathrm{al}^{(7)}$, when 90 children with CP were assessed, being $71 \%$ tetraplegic, and by Pereira Linhares ${ }^{(20)}$, who reports that this pattern of intake is independent of sex.

However, as important as energy intake, is the balance of macronutrients in the diet composition. In this sense, the studied population showed an unbalanced dietary pattern, high in fat and low in carbohydrates. Fat was represented mainly by weekly intake of cold cuts and sausages (cheesesalad, hot-dog, and fried sausage) in 58\% and savory foods (potato chips, French fries, and garlic oil) in 62\%. According to Abanto $e t$ al $^{(21)}$, there is no significant difference in healthy children and adolescents with CP and normal ones on the preference for salty snacks. Similarly, the preference for fat instead of carbohydrates is described in healthy children and adolescents ${ }^{(22)}$, which may occur, among other possibilities, due to the higher palatability of fat, the influence of the media, the possibility of eating away from home, accompanying friends in the preference for fast food, and, especially, the family eating habits ${ }^{(23-26)}$. Therefore, the feeding patterns of children and adolescents is independent of health status, pointing to the need for nutrition education in general, and in particular for those with $\mathrm{CP}$ due to the lower amount of food intake and the need for change in consistency of food.

In this study, through the food frequency questionnaire, it was observed that there was an adequate number (four to five) of meals/day and, in addition to the high consumption of fatty foods, there was little daily consumption of vegetables, fruits and liquids, not exceeding three glasses daily of $200 \mathrm{~mL}$, represented mainly by industrialized juice powder and soda. This was consumed weekly by $54 \%$ of patients, and $19 \%$ used daily. Daily bowel movements were found in about $52 \%$ of the children studied. Accordingly, Castro ${ }^{(27)}$ verified low consumption of foods that help bowel function (vegetables, leafy vegetables, fruit laxatives and increase of vegetable oils) in individuals with $\mathrm{CP}$ and observed that $94 \%$ of the sample presented low fluid intake (water, juice and tea). Among the complications associated with $\mathrm{CP}$, constipation is a consequence of the low mobility of the body, difficulty in fluid intake, and inadequate food intake, due to dysphagia and low motility, because the abdominal muscles are always rigid, which contributes to slow peristalsis and the consequent drying of feces ${ }^{(28)}$.

Exercise may benefit children with CP, improving muscle strength, cardiovascular function, and motor performance ${ }^{(29)}$. It was observed that $93 \%$ of respondents were classified as insufficiently active for physical activity of at least $30 \mathrm{~min}$ utes, twice a week.

Anthropometric data showed that the group with tetraplegia showed greater nutritional loss and that the most affected ratio is the H/A. This confirms previous results of various authors, such as Pires $e t a^{(10)}$, who also identified low values of $\mathrm{H} / \mathrm{A}$ in individuals with tetraplegia, Grammatikopoulou et al ${ }^{(30)}$, who reported in all studied sample a value $<-2$ for $\mathrm{H} / \mathrm{A}$, regardless of the gravity of the impairment, Dahlseng et al ${ }^{(31)}$, who observed that $20 \%$ of 661 diplegic and tetraplegic patients presented H/A and W/A $<-2$, and Caram et al ${ }^{(32)}$, who, analyzing all kinds of $\mathrm{CP}$, reported that $51 \%$ had values below -2 for $\mathrm{W} / \mathrm{A}$ and $39 \%$, for $\mathrm{H} / \mathrm{A}$.

Interestingly, the group with tetraplegia had higher prevalence of difficulty in swallowing and chewing, as observed by other authors, confirming the importance of chewing and swallowing for nutritional status ${ }^{(32-34)}$. The difficulty in chewing and swallowing is probably the determining factor in the nutritional status of children with CP and an early identification would allow the monitoring by suitable professionals, assisting the preparation of a more adequate diet for this population. This fact was confirmed by Souza et $a l^{(35)}$, who assessed 20 children with CP who were treated at a rehabilitation center and accompanied by a multidisciplinary team. In this group, no impairment of BMI was observed, a fact that was also observed by Pereira Linhares ${ }^{(20)}$.

It should be considered that this study is limited by the sample size, which resulted from selection by convenience. Thus, longitudinal studies are needed, with a representative sample, showing the positive influence of multidisciplinary guidance on the health status of this population, so that the public authority can be convinced that this procedure should become mandatory.

From the data collected and analyzed in the present study, it may be concluded that the children studied have inappropriate dietary patterns and impaired nutritional status, especially in relation to height. Tetraplegia imposes difficulty in chewing/swallowing and in the practice of moderate physical activity. 


\section{References}

1. Brouwer B, Ashby P. Altered corticospinal projections to lower limb motoneurons in subjects with cerebral palsy. Brain 1991;114:1395-407.

2. Piovesana AM, Val Filho JA, Lima CL, Fonseca MS, Murer AP. Encefalopatia crônica: paralisia cerebral. In: Fonseca LF, Pianetti G, Xavier CC, editors. Compêndio de neurologia infantil. Rio de Janeiro: Medsi; 2002. p. 826-37.

3. Low JA, Galbraith RS, Muir DW, Killen HL, Pater EA, Karchmar EJ. Factors associated with motor and cognitive deficits in children after intrapartum fetal hypoxia. Am J Obstet Gynecol 1984;148:533-9.

4. Rotta NT. Cerebral palsy, new therapeutic possibilities. J Pediatr (Rio J) 2002;78 (Suppl 1):S48-54.

5. Gangil A, Patwari AK, Aneja S, Ahuja B, Anand VK. Feeding problems in children with cerebral palsy. Indian Pediatr 2001;38:839-46.

6. Piccoli R, Gelio S, Fratucello A, Valletta E. Risk of low micronutrient intake in neurologically disabled children artificially fed. J Pediatr Gastroenterol Nutr 2002;35:583-4.

7. Sullivan PB, Juszczak E, Lambert BR, Rose M, Ford-Adams ME, Johnson A. Impact of feeding problems on nutritional intake and growth: Oxford Feeding Study II. Dev Med Child Neurol 2002;44:461-7.

8. Aurélio SR, Genaro KF, Macedo Filho ED. Comparative analysis of swallowing patterns between children with cerebral palsy and normal children. Rev Bras Otorrinolaringol 2002;68:167-73.

9. Samson-Fang LJ, Stevenson RD. Identification of malnutrition in children with cerebral palsy: poor performance of weight-for-height centiles. Dev Med Child Neurol 2000;42:162-8.

10. Pires PT, Matta DS, Rodrigues AM, Lopes AC, Costa RF, Gil KV. Medidas de peso e estatura de crianças e adolescentes com paralisia cerebral. Med Reabil 2007;26:11-4.

11. Santos DC, Serrano HM. Nutritional diagnostic of children and adolescentes with cerebral paralysis helped in an Apae of Vale do Aço. Nutrir Gerais [serial on the Internet]. 2007;1 [cited 2013 Jan 16]. Available from: http://www.unilestemg. br/nutrirgerais/downloads/artigos/diagnostico_nutricional.pdf

12. Rotta NT, Drachler ML, Vaitses VD, Ohlweiler L, Lago IS. Paralisia cerebral: estudo de 100 casos. Rev HCPA 1983;3:113-6.

13. Bonomo E. Como medir a ingestão alimentar? In: Dutra JE, editor. Obesidade, anemia carencial na adolescência. São Paulo: Instituto Danone; 2000. p. 117-26.

14. Dwyer J, Picciano MF, Raiten DJ; Members of the Steering Committee; National Health and Nutrition Examination Survey. Estimation of usual intakes: what we eat in America-NHANES. J Nutr 2003;133:609S-23.

15. Dietpro. Dietpro 5.5i Professional: tecnologia para nutrição [CD-ROM]. Viçosa: A.S. Sistemas; 2008

16. World Health Organization. Diet, nutrition, and the prevention of chronic diseases. Report of a WHO Study Group. [WHO Technical Report Series 797]. Geneva: WHO; 1990.

17. U.S. Department of Health and Human Services; U.S. Department of Agriculture. Dietary guidelines for Americans 2005. Washington: National Academy Press; 2005.
18. Stevenson RD. Use of segmental measures to estimate stature in children with cerebral palsy. Arch Pediatr Adolesc Med 1995;149:658-62.

19. De Onis M, Onyango AW, Borghi E, Siyam A, Nishida C, Siekmann J. Development of a WHO growth reference for school-aged children and adolescents. Bull World Health Organ 2007;85:660-7.

20. Pereira Linhares FM. Avaliação do estado nutricional de crianças com disfagia por paralisia cerebral [tese de mestrado]. Santa Maria (RS): UFSM; 2004.

21. Abanto J, Bortolotti R, Carvalho TS, Alves FB, Raggio DP, Ciamponi AL. Assessment of dietary habits of dental interest in children with cerebral palsy. Rev Inst Cienc Saude 2009;27:244-8.

22. Silva JV, Timóteo AK, Santos CD, Fontes G, Rocha EM. Food consumption of children and adolescents living in an area of invasion in Maceio, Alagoas, Brazil. Rev Bras Epidemiol 2010;13:83-93.

23. Mcdonald LA, Wearring GA, Moase $\mathrm{O}$. Factors affecting the dietary quality of adolescent girls. J Am Diet Assoc 1983;82:260-3.

24. Woodward DR. What influences adolescent food intakes? Hum Nutr Appl Nutr 1986; $40: 185-94$

25. Rees JM. The overall impact of recently developed foods on the dietary habits of adolescents. J Adolesc Health 1992;13:389-91.

26. Tojo R, Leis R, Pavon P. Nutritional needs in adolescence. Risk factors. An Esp Pediatr 1992;36 (Suppl 49):80-5.

27. Castro FF. Constipação intestinal em pacientes com paralisia cerebral: avaliação dos resultados das internações de enfermagem [tese de mestrado]. Belo Horizonte (MG): UFMG; 2009.

28. Böhmer CJ, Taminiau JA, Klinkenberg-Knol EC, Meuwissen SG. The prevalence of constipation in institutionalized people with intellectual disability. J Intellect Disabil Res 2001;45:212-8.

29. Kelly M, Darrah J. Aquatic exercise for children with cerebral palsy. Dev Med Child Neurol 2005;47:838-42.

30. Grammatikopoulou MG, Daskalou E, Tsigga M. Diet, feeding practices, and anthropometry of children and adolescents with cerebral palsy and their siblings. Nutrition 2009;25:620-6.

31. Dahlseng MO, Finbråten AK, Júlíusson PB, Skranes J, Andersen G, Vik T. Feeding problems, growth and nutritional status in children with cerebral palsy. Acta Paediatr 2012;101:92-8.

32. Caram AL, Morcillo AM, Pinto EA. Nutritional status of children with cerebral palsy. Rev Nutr 2010;23:211-9.

33. Sleigh G, Brocklehurst P. Gastrostomy feeding in cerebral palsy: a systematic review. Arch Dis Child 2004;89:534-9.

34. Sullivan PB, Juszczak E, Bachlet AM, Thomas AG, Lambert B, VernonRoberts A et al. Impact of gastrostomy tube feeding on the quality of life of carers of children with cerebral palsy. Dev Med Child Neurol 2004; 46:796-800

35. Souza KE, Sankako AN, Carvalho SM, Braccialli LM. Classification of gross motor function injury and body mass index in children with cerebral palsy. Rev Bras Crescimento Desenvolvimento Hum 2011;21:11-20. 